\title{
Embryogenic callus formation by cotyledon and leaf explants of Crambe abyssinica seedlings
}

\author{
TOMASZ FURMANEK ${ }^{1 *}$, WALENTYNA BANAŚ ${ }^{2}$ \\ ${ }^{1}$ Institute of Experimental Biology and Environmental Protection, Pomeranian University in Słupsk, Poland \\ ${ }^{2}$ Institute of Biology, University of Natural Sciences and Humanities in Siedlce, Poland \\ * Corresponding author: furmanek@apsl.edu.pl
}

\begin{abstract}
The study investigates the regeneration capacity of Crambe abyssinica via the callus phase. The conducted experiments provide an overview of various conditions appropriate for callus development and its subsequent differentiation. Explants from cotyledons and leaves of sterile 14-day-old seedlings of $C$. abyssinica cv. Mayer were used. The primary callus so obtained was subsequently utilised for the observation of embryogenesis. The best callus formation on the explants was achieved on the agar-solidified MS medium with $0.5 \mathrm{mg} \cdot \mathrm{dm}^{-3} \mathrm{NAA}$ and $0.5 \mathrm{mg} \cdot \mathrm{dm}^{-3}$ BAP or TDZ. The formation of secondary embryogenic callus was most efficient on MS medium supplemented with $0.4 \mathrm{mg} \cdot \mathrm{dm}^{-3} \mathrm{NAA}$ and $0.3 \mathrm{mg} \cdot \mathrm{dm}^{-3}$ of BAP.
\end{abstract}

Key words: Crambe abyssinica, in vitro, callus, embryogenesis

\section{Introduction}

Imminent crude oil depletion makes alternatives, such as vegetable oil, increasingly important to the chemical industry. Among oil crops, oilseed rape (Brassica napus) is the most popular crop in Poland, central and northern Europe and Canada. It is a high-yielding crop, and its cultivation conditions are well researched. Moreover, oilseed rape in vitro regeneration and transformation methods are well developed. Nonetheless, the introduction of new genetically engineered varieties has proven to be highly problematic, particularly those containing inedible industrial oils. The possibility of chance mixing the seeds of industrial oil varieties with the consumable ones cannot be excluded. Such incidents have already been reported in the case of corn (Macilwain, 2005). Cross-breeding of transgenic rape types with original or native varieties is also possible.

Therefore, the search for alternative, industry-suitable oil plants continues. One of the promising candidates is Crambe abyssinica. It belongs to the Brassicaceae family and can be successfully cultivated in a temperate climate, e.g. in Poland (Jankowski and Budzyński, 2004). Crambe abyssinica is an ideal plant for all types of genetic manipulation aimed at improving its industrial suitability. Its seeds contain high amounts of glucosinolates.
There is also a high erucic acid content (55-60\%) in its oil, making it a problematic candidate for fodder and an impossible one for human consumption since an excessive intake of erucic acid can cause health problems (Kulig et al., 2004). This eliminates the eventuality of mixing consumption seeds with industrial ones. Crambe abyssinica does not cross-breed with any other cultivated oil plant or with the majority of related wild species (Wang and Peng, 1998). Consequently, there is a very low probability of transfer of newly introduced genes into other species or even other varieties of Crambe abyssinica as it is cultivated only in few countries in a very limited area (there are only experimental cultivations in Poland).

Currently several research programmes aim at improving the qualitative characteristics of Crambe abyssinica especially in terms of yield and tolerance to stress conditions using classical plant cultivation methods. It must be noted that even the existing varieties produce yields comparable to those offered by spring oilseed rape. However, with classical methods of plant breading, it is hard to achieve desirable modifications of plant genome (e.g. qualitative change in the produced oil) in a relatively short time, therefore, biotechnological methods are recommended. Unfortunately, the conditions 
of regeneration and transformation applied successfully to other species of the Brassicaceae family are not effective in the case of Crambe abyssinica and the data on its regeneration and transformation using modified/alternative methods is relatively limited (Li et al., 2010). This study focuses on regeneration of Crambe abyssinica, cv. Mayer via the callus phase obtained from different organs of its seedlings.

\section{Materials and methods}

Seeds of Crambe abyssinica, cv. Mayer were sterilized in $0.1 \%$ solution of $\mathrm{NaOCl}$ mixed with Tween 20 (1 drop per $100 \mathrm{~cm}^{3}$ of sterilizing agent), rinsed three times with sterile distilled water and transferred to the agar-solidified Murashige and Skoog (MS) medium $\left(7 \mathrm{~g} \cdot \mathrm{dm}^{-3}\right)$. Fourteenday-old seedlings were used to prepare explants from cotyledons and leaves which were cut along the main vein into two pieces and then transferred to different types of MS medium (Tab. 1). The effectiveness of callus formation was assessed after 14 days and the experiment was repeated three times. Forty-five explants (5 containers with 9 explants each) were laid onto each type of the medium in every experiment. The callus (Fig. 1) was subsequently transferred to new MS media supplemented with selected vitamins and growth hormones (Tab. 2). Its development was analysed after 4 weeks. All cultures were incubated at $23^{\circ} \mathrm{C}$ under 16 -hours photoperiod in the growth chamber. The explants/calluses were placed 35 $\mathrm{cm}$ below the light source (fluorescence tubes “PIL1-LF36W/54-765" - 8 tubes/1 m).

\section{Results and discussion}

Sterilization of plant material is the first stage in setting up an in vitro culture. In the present study, several sterilizing agents were tested (data not shown). Most effective seed sterilization was achieved with $0.1 \%$ solution of $\mathrm{NaOCl}$ mixed with a small amount of Tween 20 . This sterilizing agent resulted in a low infection rate and healthy seedling growth.

The success of an in vitro culture depends not only on the initial sterile material but also on other factors (Gaj, 2001) such as, appropriate medium, proper conditions in the growth chamber, and correct choice of explants.

In this study, agar-solidified MS medium (a universal medium applied in numerous researches - Pinto et al., 2008). Sterile Crambe abyssinica seedlings were grown

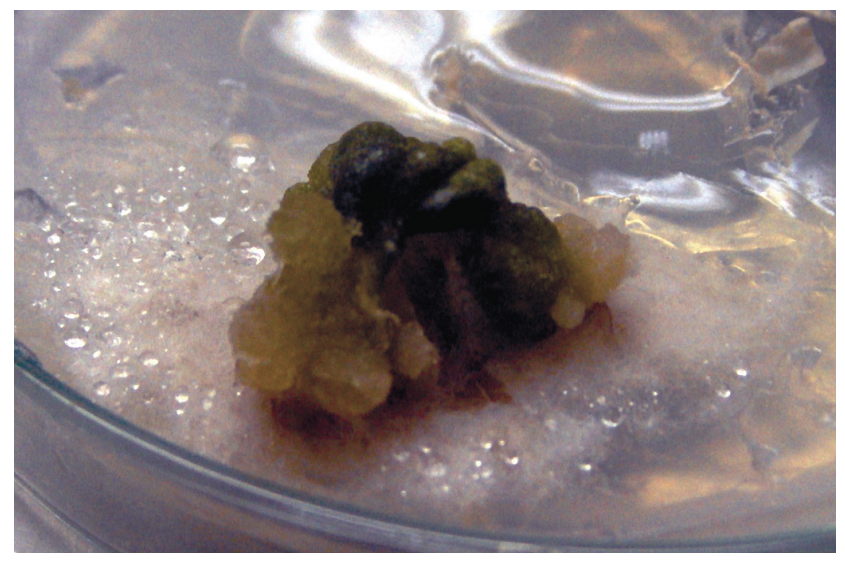

Fig. 1. Callus formed on the cotyledon explant

on the basic MS medium. In the following experiments, however, we used MS medium with different combinations of vitamins and growth regulators selected based on our own experience and the data from similar studies on other species (Zanecka-Dziubak and Łuczkiewicz, 2000; Doliński, 2004; Nhut et al., 2006; Szczygieł, 2005; Sankar et al., 2008). Literature insights were also helpful in selecting proper growth conditions in the growth chamber (Kumar et al., 2002; Doliński, 2004; Jevremovic and Radojevic, 2005).

In the studies on plant regeneration through the callus stage (i.e. through somatic embryogenesis) explants of different origins are used. In the presented research, cotyledon and leaf explants from 14-day-old in vitro grown seedlings were utilized. Internal tissue development was observed within the first days after explant's transfer to the medium. Both cotyledon and leaf explants increased their sizes. The surface of explants was bent and twisted, and the callus developed at the points of contact with the medium (Fig. 1). The callus from leaf explants which developed two weeks after the transfer was amorphous (loose and friable). It developed from every explant grown on the medium supplemented with synthetic auxin (NAA) and one of the synthetic cytokinins: BAP or TDZ. When NAA was substituted by IAA (natural auxin), the callus either did not develop at all (IAA in combination with BAP) or was formed on a few explants only (IAA with TDZ) (Tab. 1). The development of callus was also observed in the medium with auxins only (natural IAA plus synthetic NAA). In the case of cotyledon explants similar results, to those obtained from leaf explants, were also observed (Tab. 1). The only difference observed was that in most instances, the so- 
Table 1. Frequency of callus tissue formation (2- week-old cultures) on leaf and cotyledon explants of Crambe abysinica seedlings, according to the medium composition

\begin{tabular}{c|c|c|c|c}
\hline \multirow{2}{*}{$\begin{array}{c}\text { Growth regulators } \\
{\left[\mathrm{mg} \cdot \mathrm{dm}^{-3} \text { of medium] }\right]}\end{array}$} & \multicolumn{2}{|c|}{ leaf explants } & \multicolumn{2}{c}{ cotyledon explants } \\
\cline { 2 - 5 } & $\begin{array}{c}\text { unorganized, } \\
\text { amorphous callus }\end{array}$ & $\begin{array}{c}\text { organized } \\
\text { callus }\end{array}$ & $\begin{array}{c}\text { unorganized, } \\
\text { amorphous callus }\end{array}$ & $\begin{array}{c}\text { organized } \\
\text { callus }\end{array}$ \\
\hline $0.5 \mathrm{IAA}+0.5 \mathrm{BAP}$ & 0 & 0 & 20 & 0 \\
\hline $0.5 \mathrm{IAA}+0.5 \mathrm{TDZ}$ & 20 & 0 & 20 & 0 \\
\hline $0.5 \mathrm{NAA}+0.5 \mathrm{BAP}$ & 100 & 0 & 0 & 100 \\
\hline $0.5 \mathrm{NAA}+0.5 \mathrm{TDZ}$ & 100 & 0 & 0 & 100 \\
\hline $0.2 \mathrm{IAA}+0.2 \mathrm{NAA}$ & 100 & 0 & 45 & 30 \\
\hline $0.2 \mathrm{IAA}+0.3 \mathrm{NAA}$ & 70 & 0 & 0 & 75 \\
\hline
\end{tabular}

In addition to the growth regulators, the media contained different vitamins and amino acids: $\mathrm{B} 1, \mathrm{~B} 6$, glycine $\left[0.5 \mathrm{mg} \cdot \mathrm{dm}^{-3}\right.$ of medium]; PP $\left[0.1 \mathrm{mg} \cdot \mathrm{dm}^{-3}\right.$ of medium]

Table 2. Secondary callus formation (organogenic and non-organogenic) on the fragments of primary leaves and cotyledons' callus of Crambe abyssinica seedlings, according to the medium composition

\begin{tabular}{c|c|c|c|c}
\hline \multirow{2}{*}{$\begin{array}{c}\text { Growth hormones } \\
{\left[\mathrm{mg} \cdot \mathrm{dm}^{-3} \text { of medium }\right]}\end{array}$} & \multicolumn{2}{|c}{ Type of secondary callus formed on the fragments of primary callus } \\
\cline { 2 - 5 } & $\begin{array}{c}\text { embryogenic } \\
\text { callus }\end{array}$ & $\begin{array}{c}\text { non-embryogenic } \\
\text { callus }\end{array}$ & $\begin{array}{c}\text { embryogenic } \\
\text { callus }\end{array}$ & $\begin{array}{c}\text { non-embryogenic } \\
\text { callus }\end{array}$ \\
\hline $0.1 \mathrm{NAA}+0.3 \mathrm{BAP}$ & 15 & 95 & 22 & 78 \\
\hline $0.4 \mathrm{NAA}+0.3 \mathrm{BAP}$ & 18 & 82 & 26 & 74 \\
\hline $0.6 \mathrm{NAA}+0.3 \mathrm{BAP}$ & 12 & 88 & 20 & 80 \\
\hline $0.6 \mathrm{NAA}+0.2 \mathrm{BAP}$ & 0 & 100 & 12 & 88 \\
\hline $0.6 \mathrm{NAA}+0.1 \mathrm{BAP}$ & 0 & 100 & 5 & 95 \\
\hline $0.4 \mathrm{NAA}+0.1 \mathrm{BAP}$ & 0 & 100 & 10 & 90 \\
\hline
\end{tabular}

In addition to the growth regulators the media contained different vitamins and amino acids: B1, B6 $\left[0.5 \mathrm{mg} \cdot \mathrm{dm}^{-3}\right.$ of medium]; PP [0.2 $\mathrm{mg} \cdot \mathrm{dm}^{-3}$ of medium]; glycine [0.4 $\mathrm{mg} \cdot \mathrm{dm}^{-3}$ of medium]

called 'organized callus' was developed. It had an intense green colour, a compact structure, was nodular and did not disintegrate during transfers. Therefore, the type of callus formed depended heavily on the explants used, while the applied growth regulators influenced the intensity of explants' callusing activity. The type of applied auxin seems to be the most important for the initiation of explant callusing in Crambe abyssinica seedlings. IAA was not useful probably due to its quick inactivation by explants. On the other hand, the application of NAA especially together with one of the synthetic cytokinins, BAP or TDZ, produced quite satisfactory results. This combination of growth regulators caused $100 \%$ callus formation in both cotyledon and leaf explants (Tab. 1). It is possible that similar callusing activity can be achieved with other synthetic auxins. For instance, Doliński (2004) used a medium supplemented with 2,4-D and BAP to initiate callus formation in leaf explants of ginseng. However, in the present study only combinations of growth hormones given in Table 1 were tested.

To obtain appropriate amounts of callus tissue, passage to a fresh medium is necessary (Szczygieł, 2005). In this study, the callus that developed on explants (either unorganized - formed on leaf explants or organized - formed on cotyledon explants) was fragmented and transferred to media containing different composition of growth hormones (Tab. 2). New callus grew around the old one and formed compact, granular structures of 


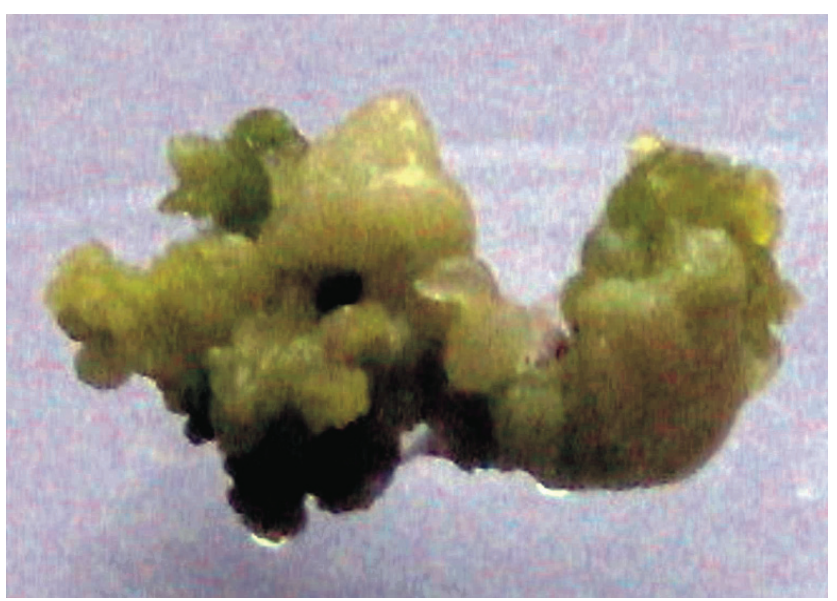

Fig. 2. Organogenic callus

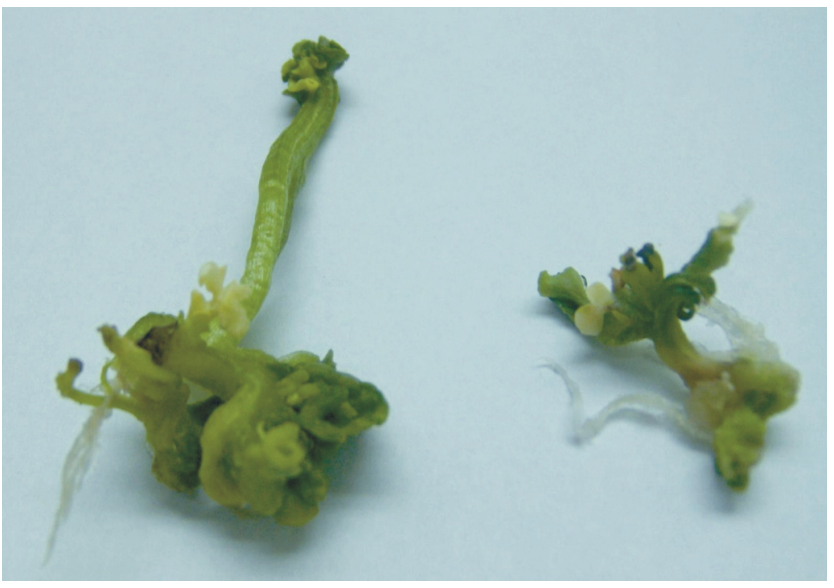

Fig. 3. Malformed shoots, primordia and roots formed on the organogenic callus

greenish-yellow colour in case of both unorganized leaf callus and organized cotyledon callus.

Several days after the passage, the new callus that developed on some fragments of the old one started to differentiate into organogenic callus (Fig. 2). First shoots and roots primordia emerged and transformed over the time (about 4 weeks) into roots, malformed leaves and shoots. The proportion of organogenic callus in the newly developed callus depended both on its origin (leaf or cotyledon callus) and on the concentration of the applied growth regulators.

The highest percentage of embryogenic callus (accounting for $18 \%$ of the newly developed callus in case of the leaf callus and $26 \%$ in case of cotyledon callus - Tab. 2) was recorded when the concentration ratio of NAA to BAP in the medium was $4 / 3\left(0.4 \mathrm{mg} \cdot \mathrm{dm}^{-3} \mathrm{NAA}\right.$ and $\left.0.3 \mathrm{mg} \cdot \mathrm{dm}^{-3} \mathrm{BAP}\right)$. In the case of leaf callus, the embryogenic characteristics of the new callus were lost when the ratio of NAA to BAP in the medium exceeded 2. Cotyledon callus formed embryogenic callus in a broader range of the NAA/BAP ratios. However, also in this case, higher ratios (3 and above) resulted in a lower percentage of transplanted fragments of callus, on which embryogenic callus developed (Tab. 2). In the case of the embryogenic callus of both, the leaves and the cotyledons, high NAA/BAP ratio ( 3 and above) caused it to develop mainly into roots. When the ratio was around 2 , malformed leaves were created. Ratio approaching 1 resulted in the formation of misshaped shoots, primordia and roots (Fig. 3).

The auxin to cytokinin ratio that stimulates embryogenic callus formation is, however, not universal for all species. For example, Nhut and colleagues (2006) recorded the most intensive embryogenic callus formation in the cultures of Lilium longiflorum when the medium was supplemented with $1 \mathrm{mg} \cdot \mathrm{dm}^{-3} \mathrm{NAA}$ and $0.2 \mathrm{mg} \cdot \mathrm{dm}^{-3}$ TDZ (auxin/cytokinin ratio equal to 5). Zandecka-Dziubak and Łuczkiewicz (2000) observed embryogenic callus formation in the cultures of Camelina sativa using different combinations of NAA/BAP, with the best results at $6 / 5$ ratio. According to Sankar and colleagues (2008), the optimal auxin to cytokinin ratio for Camptotheca acuminate is equal to 2, however, the content of BAP in the medium must be relatively high (equal to $0.5 \mathrm{mg} \cdot \mathrm{dm}^{-3}$ ).

In the case of Crambe abyssinica - a medium supplemented with $0.4 \mathrm{mg} \cdot \mathrm{dm}^{-3} \mathrm{NAA}$ and $0.3 \mathrm{mg} \cdot \mathrm{dm}^{-3} \mathrm{BAP}$, produces satisfactory results. About $20 \%$ of transplanted primary callus fragments formed the embryogenic callus already after the first passage. Moreover, after a longer cultivation period, the callus developed into deformed shoots and roots. It seems that the regeneration of the entire Crambe abyssinica plant via somatic embryogeneses is achievable if a proper growth medium is ascertained. Further studies in this direction are foreseen.

\section{Abbreviation}

MS - Murashige \& Skoog medium; IAA - indoleacetic acid; NAA - naftalene acetic acid; BAP - benzylaminopurine; TDZ - thidiazuron; PP - nicotinamide; B1 - thiamine; B6 - pyridoxine

\section{References}

Doliński R. (2004) Indukcja kalusa i regeneracja roślin żeńszenia amerykańskiego (Panax quinquef olius L). Ann. UMCS: Sec. E 59(1): 1131-1138. 
Gaj M. (2001) Somatyczna embriogeneza w kulturach in vitro Arabidopsis thaliana (L). Katowice, Uniw. Śl.

Jankowski K., Budzyński W. (2004) Potencjał energetyczny roślin oleistych. Probl. Ekol. 8(1): 31-38.

Jevremovic S., Radojevic L. (2005) Establishment of efficient regeneration protocol from leaf explants of Iris pumila shoots cultured in vitro. Sci. Hort. 108: 100-103.

Kulig B., Szafrański W., Kołodziej J. (2004) Wpływ przebiegu pogody $w$ okresie wegetacji na plonowanie $i$ architekture łanu katranu abisyńskiego. Acta Agrophys. 3(1): 107-115.

Kumar H.G.A., Murthya H.N., Paek K.Y. Kumar H.G.A., Murthya H.N., Paek K.Y. (2002) Embryogenesis and plant regeneration from anther cultures of Cucumis sativus $L$. Sci. Hort. 98: 213-222.

Li X., Ahlman A., Yan X., Lindgren H., Zhu L-H. (2010) Genetic transformation of the oilseed crop Crambe abyssinica. Plant Cell Tiss. Organ. Cult. 100(2): 149-156.

Macilwain C. (2005) Stray seeds had antibiotic-resistant genes. Nature 434: 548-548.

Nhut D.T., Hanh N.T.M., Tuan P.Q., Nguyet L.T.M., Tram N.T.H., Chinh N.Ch., Ngguyen N.H., Vinh D.N. (2006) Liquid culture as a positive condition to induce and enhance quality and guanity of somatic embryogenesis of Lilium longiflorum. Sci. Hort. 110: 93-97.

Pinto G., Silna S., Park Y., Neves L., Araújo C., Santos C. (2008) Factors influencing somatic embryogenesis induction in Eucalyptus globules. Plant Cell Tiss. Organ. Cult. 95(1): 79-88.

Sankar T., Saare-Surinski K., Lieberei R. (2008) Plant regeneration via somatic embryogenesis of Camptotheca acuminata in temporary immersion system (TIS). Plant Cell Tiss. Organ. Cult. 95(2): 163-173.

Szczygieł K. (2005) Somatyczna embriogeneza - alternatywny sposób uzyskiwania wyselekcjonowanego materiału sadzeniowego gatunków drzew iglastych. Leśne Pr. Bad. 3: 71-92.

Wang Y., Peng P. (1998) Intergeneric hybridization between Brassica species and Crambe abyssinica. Euphytica 101: 1-7.

Zandecka-Dziubak J., Łuczkiewicz T. (2000) Efektywność embriogenezy somatycznej $w$ kulturach in vitro Inianki siewnej (Camelina sativa L.). Rośl. Oleiste 21: 615-620. 